\title{
Host species of the non-indigenous brittle star Ophiothela mirabilis (Echinodermata: Ophiuroidea): an invasive generalist in Brazil?
}

\author{
Marcelo Checoli Mantelatto 1,6, Lara Figueiredo Vidon², Rosana Beatriz Silveira², Carla Menegola ${ }^{3,6}$, \\ Rosana Moreira da Rocha ${ }^{4}$ and Joel Christopher Creed ${ }^{5,6^{*}}$
}

\begin{abstract}
Background: The brittle star Ophiothela mirabilis has recently invaded and is expanding its range in the southwest Atlantic.

Results: Here we report a total of 29 novel host taxons/functional group (ten sponges, six cnidarians, five ascidians, four echinoderms, two algae, one bryozoan and a seahorse) used by O. mirabilis at different sites at Ilha Grande Bay, Brazil.

Conclusions: The large number of species colonized by the ophiuroids suggests that they have become opportunistic and generalist in relation to their host species. The yellow-orange Brazilian lineage did not use camouflage reported in other studies, as they were highly visible and contrasted in color to many host species which suggests that they may possess some kind of predator deterrence. The high abundances of $O$. mirabilis registered here also suggest potential impacts to their hosts which need further study.
\end{abstract}

Keywords: Associations, Brittle stars, Echinodermata, Epizoic ophiuroids, Ilha Grande Bay, Invasive species, Non-indigenous species, Species interaction

\section{Background}

Invasive species can cause ecological, economic and social problems, including loss of native species and changes in communities and ecosystems, altering their functions, structure and services (Pimentel et al. 2005). Ballast water and hull fouling are considered the main vectors for non-indigenous species (NIS) to be introduced into novel marine environments (Ruiz et al. 1997) so an increase in shipping activities may increase the number of invasive species in a given region.

The brittle star Ophiothela mirabilis Verrill, 1867, a small epizoic six-armed ophiuroid that range in colour

\footnotetext{
* Correspondence: jcreed@uerj.br

${ }^{5}$ Departamento de Ecologia, Instituto de Biologia Roberto Alcântara Gomes, Universidade do Estado do Rio de Janeiro, Rua Francisco Xavier 524, PHLC, sala 220, CEP 20559-900 Rio de Janeiro, RJ, Brazil

${ }^{6}$ Coral-Sol Research, Technological Development and Innovation Network, Rio de Janeiro, Brazil

Full list of author information is available at the end of the article
}

from yellow to orange, whose original distribution is the Pacific Ocean, has recently invaded and is expanding in southwest Atlantic waters in Brazil (Hendler et al. 2012). Initially reported at Ilha do Pai, Rio de Janeiro State, in 2000, the species can now be found south to São Paulo, Paraná and Santa Catarina, and north to Espírito Santo, Bahia (Hendler et al. 2012) and more recently Pernambuco States (R.B.S., personal observation), along an extension of approximately $2700 \mathrm{~km}$ of the Brazilian coastline (Fig. 1a). The ophiuroid was also reported as invasive in French Guiana (Hendler and Brugneaux 2013), in St. Vincent (Hendler et al. 2012) and in Tobago (Hendler and Brugneaux 2013) (Fig. 1a). Its presence near Brazilian and Caribbean ports suggests that the invasive ophiuroid may have been introduced by shipping, in ballast water or associated with fouling communities encrusting on the ships hulls (Hendler et al. 2012; Hendler and Brugneaux 2013), although the 


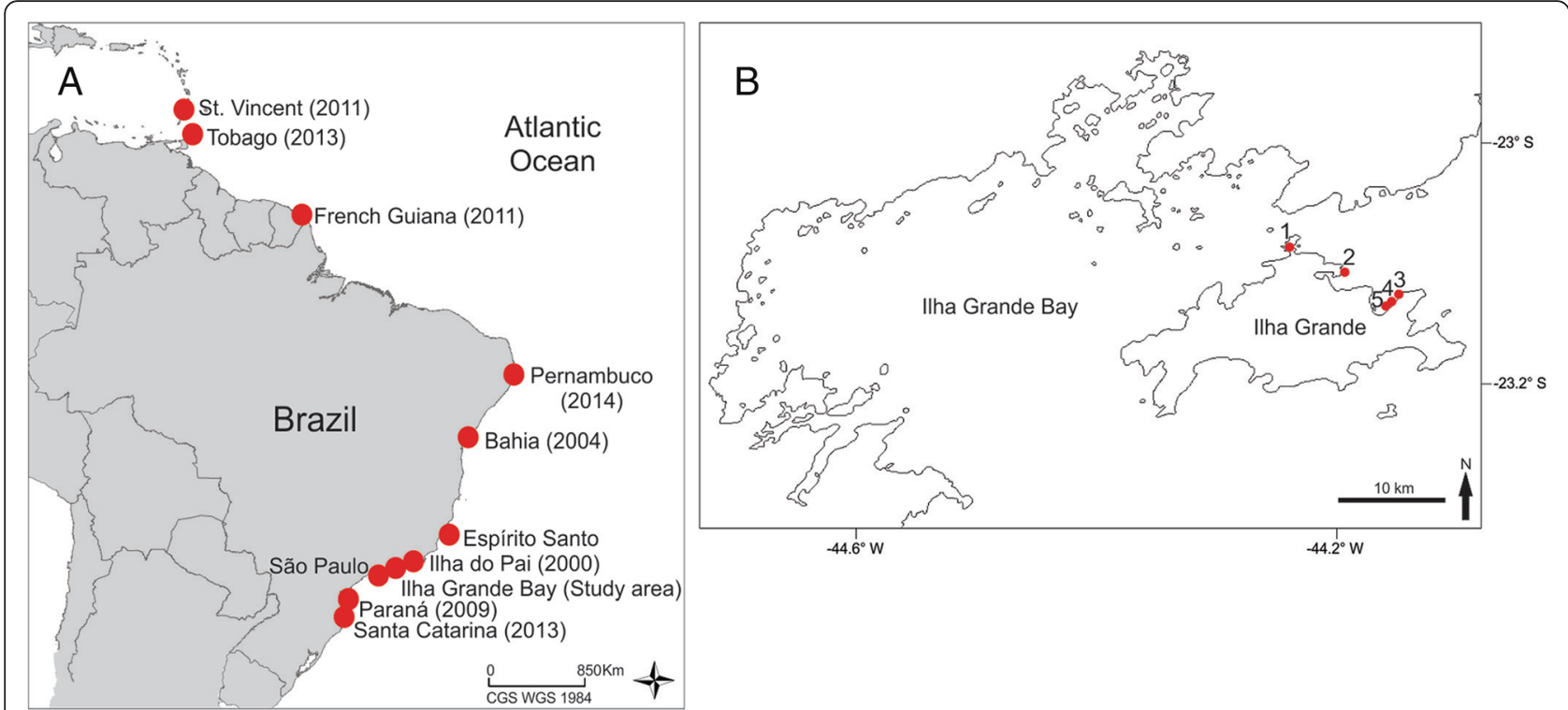

Fig. 1 a Records, with timeframe, of Ophiothela mirabilis in the southwest Atlantic and Caribbean. b The study sites at Ilha Grande Bay, Rio de Janeiro, Brazil. (1) Lagoa Azul, (2) Barretos, (3) Morcegos, (4) Abraãozinho right and (5) Abraãozinho left

natural transport by oceanic currents cannot be ruled out (Hendler and Brugneaux 2013).

The sexual reproduction of $O$. mirabilis has not been investigated yet, so we do not know if there is a planktonic larval stage that could naturally spread by currents or be transported inside ballast water tanks (Hendler and Brugneaux 2013). The species does reproduce asexually by fissiparity, which permits an individual to split the disc in two parts and regenerate the missing part, what facilitates its proliferation (Hendler and Brugneaux 2013) and which can allow it to achieve high densities on its hosts. In general the most commonly observed hosts of brittle stars include sponges, cnidarians, bryozoans, sea urchins and algae (Mladenov et al. 1983; Mladenov and Emson 1988; Hickman 1998; Tahera 2001; Mosher and Watling 2009; Hendler and Brugneaux 2013) which may provide refugia from predation, habitat and feeding space. After colonization it is possible that the ophiuroids crawl out and disperse short distances to other nearby species and may also disperse by rafting on algal and invertebrate fragments (Mladenov and Emson 1988; Hendler et al. 1999). These reproduction modes and behavior might give $O$. mirabilis a greater adaptive advantage in the colonization of new environments allowing it to rapidly expand its distribution.

In the Atlantic Hendler et al. (2012) comment that at least 20 host species have been observed, including gorgonians, sponges, Hydrozoa, Bryozoa, Zoantharia and algae (Hendler and Brugneaux 2013). In Brazil, more than 15 years after invasion most hosts have not yet been identified to species level (with the exception of Mycale angulosa (Duchassaing \& Michelotti, 1864) and
Leptogorgia punicea (Milne Edwards \& Haime, 1857) (Hendler et al. 2012). Since the species is expanding its range (reported along $\sim 2700 \mathrm{~km}$ of the Brazilian coastline in 15 years) and becoming invasive through the Atlantic and Caribbean Sea (which have some of their flora and fauna in common), it is important to know the identity of the species that are colonized by $O$. mirabilis in order to plan studies that will address the possible impact of the epibiont on its most common hosts.

Ilha Grande Bay is located about $110 \mathrm{~km}$ to the west of the site where $O$. mirabilis was reported for the first time in the Atlantic and the species can be found there at many sites and on a number of different hosts. The aim of this study is to report interactions between host species and the invasive $O$. mirabilis on rocky reefs at Ilha Grande Bay, Rio de Janeiro, Brazil.

\section{Results and discussion}

A total of 20 invertebrate species were registered to be used as hosts by O. mirabilis: seven sponges (Fig. 2): Desmapsamma anchorata (Carter, 1882), Mycale americana van Soest, 1984, Mycale angulosa, Tedania ignis (Duchassaing \& Michelotti, 1864), Haliclona manglaris Alcolado, 1984, Dysidea etheria de Laubenfels, 1936 and Chelonaplysilla erecta (Row, 1911); five cnidarians (Fig. 3): Leptogorgia punicea, Leptogorgia setacea (Pallas, 1766), Heterogorgia uatumani Barreira \& Castro, 1990, Palythoa caribaeorum (Duchassaing \& Michelotti, 1860) and Carijoa riisei (Duchassaing \& Michelotti, 1860); five ascidians (Fig. 4): the solitary Phallusia nigra Savigny, 1816 and the colonials Lissoclinum cf. abdominale Monniot, 1983, Didemnum cineraceum (Sluiter, 1898), Clavelina 


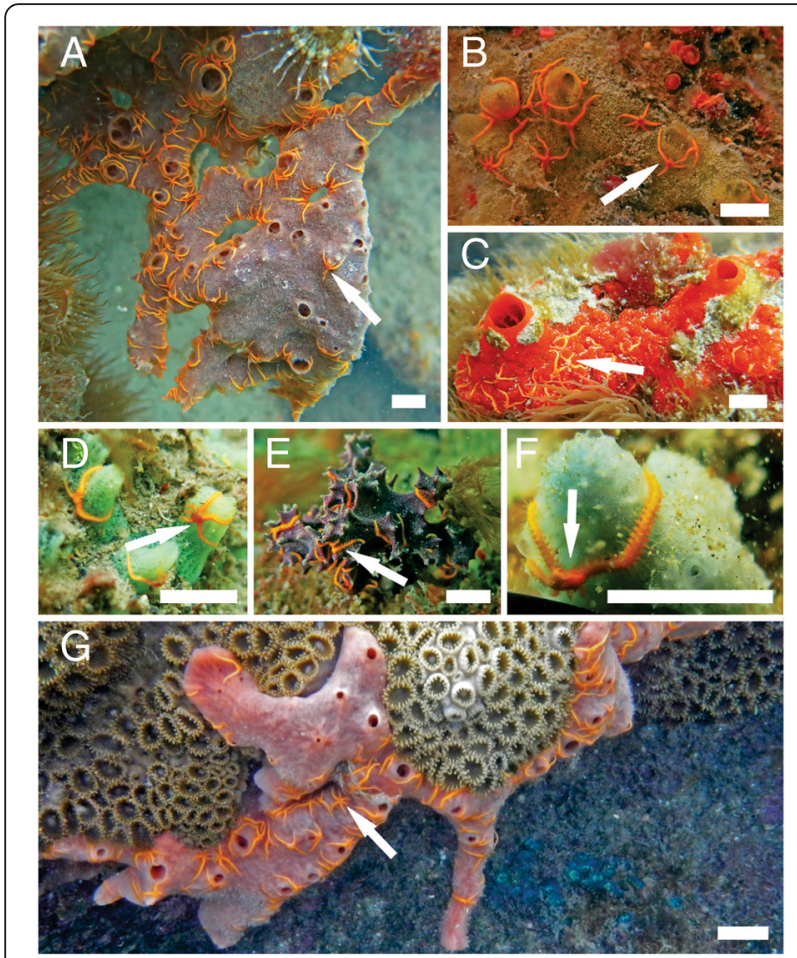

Fig. 2 Sponges used by Ophiothela mirabilis (arrowed): (a) Mycale angulosa, (b) Mycale americana (c) Tedania ignis, (d) Haliclona manglaris, (e) Chelonaplysilla erecta, (f) Dysidea etheria and (g) Desmapsamma anchorata. Images $\mathbf{a}$ and $\mathbf{c}$ were photographed at Abraãozinho left; $\mathbf{b}, \mathbf{d}$, e and $\mathbf{f}$ at Abraãozinho right; $\mathbf{g}$ at Morcegos. Scale bars: $1 \mathrm{~cm}$ oblonga Herdman, 1880 and Symplegma rubra Monniot, 1972; one bryozoan (Fig. 5a): Schizoporella sp. and two echinoderms (Fig. 5b-c): Echinometra lucunter (Linnaeus, 1758) and Isostichopus badionotus (Selenka, 1867). General in situ observations combined with the photographs indentified the two Leptogorgia species (Fig. 3b, d), C. riisei (Fig. 3c) D. anchorata (Fig. 2a) and $M$. angulosa (Fig. 2g) as being most densely covered by $O$. mirabilis.

Regarding differences between sites Abraãozinho right had the highest number of host species associated with Ophiothela mirabilis (17 species), followed by Abraãozinho left (12 species), Morcegos (eight species) and Lagoa Azul (three species) (Table 1). O. mirabilis was not found at Barretos. Carijoa riisei was most frequently colonized by O. mirabilis (at four locations) and followed by Leptogorgia punicea, Schizoporella sp., Desmapsamma anchorata and the two Mycale species at three of them.

The diversity of taxons and the relatively large number of species colonized by $O$. mirabilis within this small region suggest that the ophiuroid is quite an opportunistic and generalist species in relation to its host species. Gorgonians and sponges are also the main hosts colonized by $O$. mirabilis within its natural range in the eastern

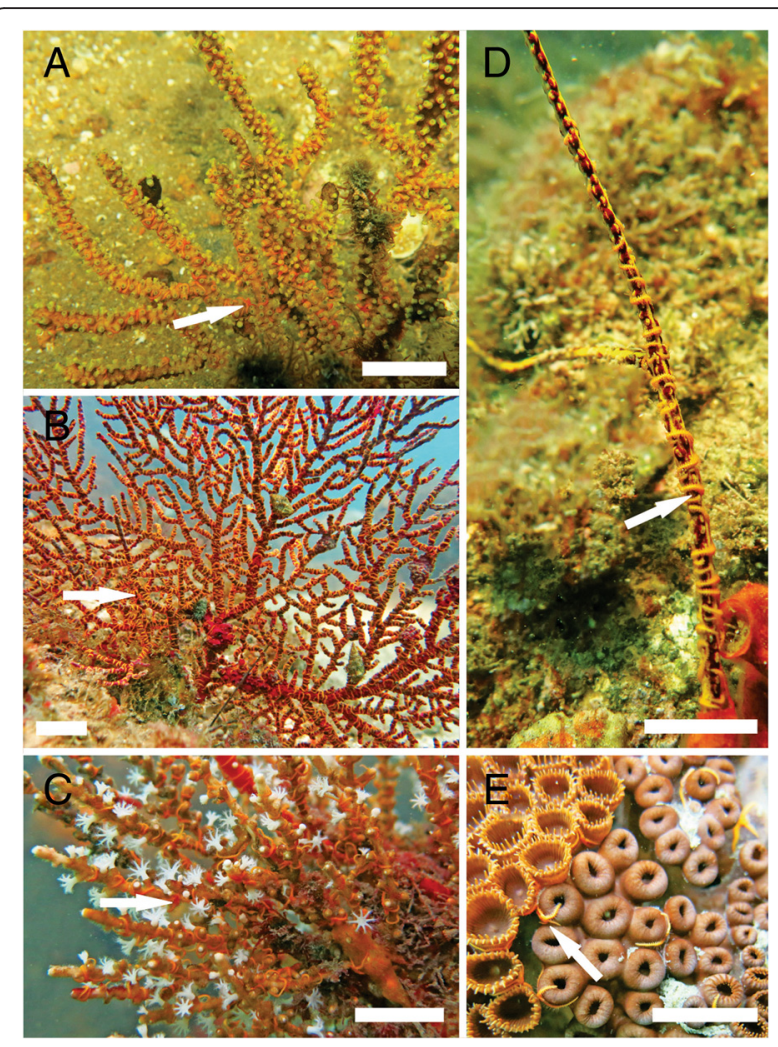

Fig. 3 Cnidarians used by Ophiothela mirabilis (arrowed): (a) Heterogorgia uatumani, (b) Leptogorgia punicea, (c) Carijoa riisei, (d) Leptogorgia setacea and (e) Palythoa caribaeorum. Images $\mathbf{a}$ and $\mathbf{b}$ photographed at Morcegos; b, c and e at Abraãozinho right. Scale bars: $2 \mathrm{~cm}$

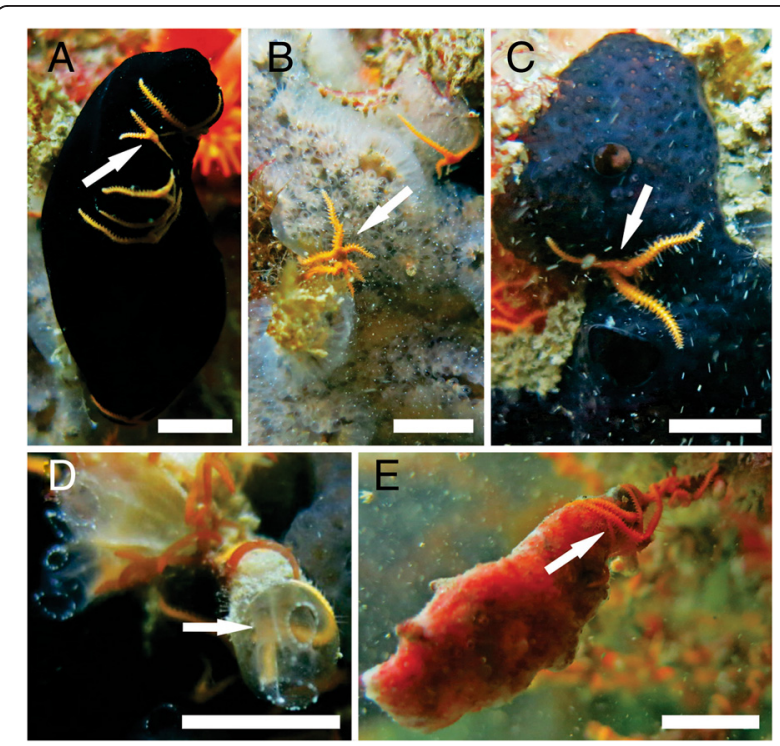

Fig. 4 Ascidians used by Ophiothela mirabilis (arrowed): (a) Phallusia nigra, (b) Lissoclinum cf. abdominale, (c) Didemnum cineraceum, (d) Clavelina oblonga and (e) Symplegma rubra. Images $\mathbf{a}, \mathbf{b}$ and $\mathbf{e}$ photographed at Abraãozinho right; $\mathbf{c}$ and $\mathbf{d}$ at Abraãozinho left. Scale bars: $1 \mathrm{~cm}$ 


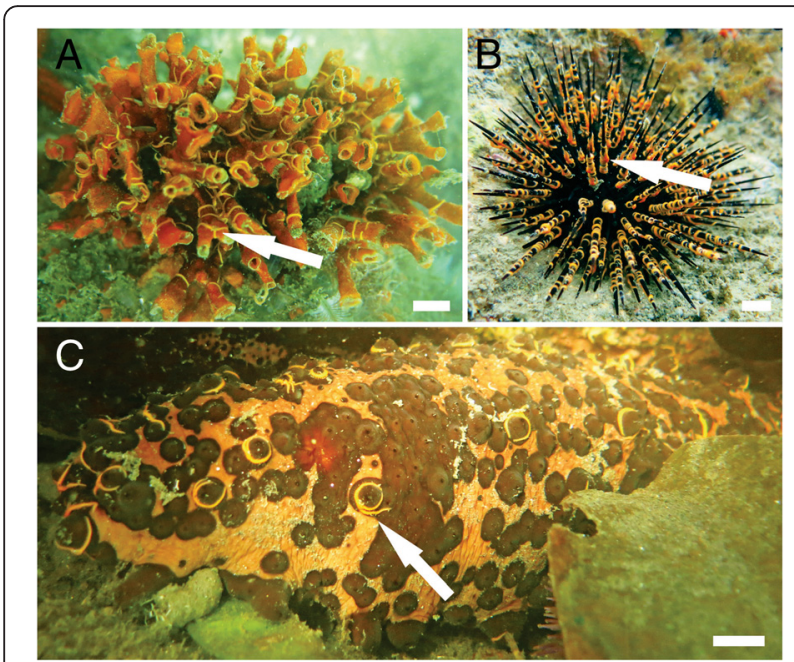

Fig. 5 Bryozoan and echinoderms used by Ophiothela mirabilis (arrowed): (a) Schizoporella sp., (b) Echinometra lucunter and (c) Isostichopus badionotus. Images a and c photographed at Morcegos; $B$ at Abraãozinho left. Scale bars: $1 \mathrm{~cm}$

Pacific (Hickman 1998; Alvarado and Fernández 2005; Neira and Cantera 2005; Granja-Fernández and LópezPérez 2011; Granja-Fernández et al. 2014). On the other hand, our observation of this brittle star on ascidians, bryozoans and a sea cucumber significantly increases our knowledge of possible hosts for the species and raises the question as to whether this particular lineage of yellow-orange $O$. mirabilis is more generalist than the others (and if this is the case, whether this behavior favors its spread).

This study consolidates a couple of previous record of the epibiosis of $O$. mirabilis on sponges in southeast Brazil; Hajdu et al. (2011) include photographic records of this association in six species on the coast of northeast Brazil at Bahia (Monanchora arbuscula (Duchassaing \& Michelotti, 1864), Callyspongia sp. 1 and sp. 2, Haliclona melana Muricy \& Ribeiro, 1999, D. anchorata and D. etheria) and Hendler et al. (2012) mention M. angulosa at São Paulo. Our results thus add four new host species and reconfirm D. anchorata, D. etheria and M. angulosa, making a total of 11 known sponge hosts of $O$. mirabilis.

Although we report here the first case of ascidians being used by $O$. mirabilis, ascidian epibiosis is well known, though it comprises especially sessile organisms such as algae, bryozoans, hydrozoans and even other ascidians that recruit on the tunics of solitary individuals, especially in the Pyuridae (Monniot et al. 1991). For example the genus Microcosmus is so named because of the large number of epibionts that cover the individuals, which can barely be seen due to the extensive cover but neither it nor two other species in the Pyruidae (Herdmania pallida (Heller, 1878) and Pyura sp.) were seen with the ophiuroid in this survey. Not all species allow recruitment on their tunics and most examples come from the Aplousobranchia (mostly colonial ascidians) and Phlebobranchia, orders to which all the ascidian hosts found in this study belong. The presence of $O$. mirabilis on $P$. nigra is especially striking, as the tunic is very acid $(\mathrm{pH} \approx 2$, Stoecker 1978) and usually completely devoid of epibionts. A recent study of the relationship of this tropical ascidian with a bivalve that lives in the tunic of ascidians showed that $P$. nigra was the only tested Phlebobranch not colonized, probably because of the highly acidic tunic (Cañete and Rocha 2013). Nevertheless, another ophiuroid, Ophiothrix angulata (Say, 1825), has been reported on P. nigra in Jamaica (Goodbody 1962) and in Panama (Collin et al. 2005). It is possible that the ophiuroids can climb on $P$. nigras's tunic because their skeleton is internal and protected from the acidic surface by the epidermis. The host ascidia $D$. cineraceum also has a very acid tunic $(\mathrm{pH} \approx 1.5)$, but there is no data for the other ascidian host species - it would be interesting to test if all are similarly acidic. Also striking is the presence of $O$. mirabilis on colonies with a very delicate and mucous tunic, such as Lissoclinum $c f$. abdominal, whose slippery consistency is thought to impede larval recruitment (Osman and Whitlatch 1995); it seems that the presence and movement of the ophiuroid does not disrupt the tunic surface.

Our field observations suggest that epibionts may be found to occur at higher densities on the octocorals $C$. riisei and Leptogorgia spp. and the sponges $D$. anchorata and $M$. angulosa, since abundances of $O$. mirabilis generally appeared to be greater on these species. Notwithstanding, further studies are needed to confirm this because the biological invasion is ongoing and the density on a single host individual may be more a function of how long ago O. mirabilis established rather than the basibiont species. Some authors suggest a commensal relationship between octocorals and brittle stars, since no benefit or disadvantaged to the octocoral has been reported and the brittle stars benefit from protection and more efficient suspension feeding by being above the bottom (Mosher and Watling 2009). Other species of the genus Ophiothela have also been recorded on gorgonians, as on the Karachi coast in the North Arabian Sea, with "no indication that they affect host survival" (Tahera 2001). Furthermore, brittle stars can feed on mucus from the coral colony or capture small planktonic organisms with their tube feet and arm spines (Mosher and Watling 2009). The ophiuroids may benefit from host sponges by more efficient suspension feeding by making use of their internal currents (Sivadas et al. 2014).

Despite the large number of species reported here in association with $O$. mirabilis, the sample area is quite small given the extent and diversity of environments of 
Table 1 Host species of the invasive brittle star Ophiothela mirabilis found at different locations at Ilha Grande Bay, Brazil

\begin{tabular}{|c|c|c|c|c|}
\hline Taxon & Lagoa Azul & Morcegos & Abraãozinho left & Abraãozinho right \\
\hline \multicolumn{5}{|l|}{ Porifera } \\
\hline Desmapsamma anchorata (Carter, 1882) & & $x$ & $x$ & $x$ \\
\hline Mycale americana (van Soest, 1984) & $x$ & & $x$ & $x$ \\
\hline Mycale angulosa (Duchassaing \& Michelotti, 1864) & & $x$ & $x$ & $x$ \\
\hline Tedania ignis (Duchassaing \& Michelotti, 1864) & & & $x$ & $x$ \\
\hline Haliclona manglaris Alcolado, 1984 & & & & $x$ \\
\hline Dysidea etheria de Laubenfels, 1936 & & & & $x$ \\
\hline Chelonaplysilla erecta (Row, 1911) & & & & $x$ \\
\hline \multicolumn{5}{|l|}{ Cnidaria } \\
\hline Leptogorgia punicea (Milne Edwards \& Haime, 1857) & & $x$ & $x$ & $x$ \\
\hline Leptogorgia setacea (Pallas, 1766) & & $x$ & & $x$ \\
\hline Heterogorgia uatumani (Barreira \& Castro, 1990) & & $x$ & & $x$ \\
\hline Palythoa caribaeorum (Duchassaing \& Michelotti, 1860) & & & $x$ & $x$ \\
\hline Carijoa riisei (Duchassaing \& Michelotti, 1860) & $x$ & $x$ & $x$ & $x$ \\
\hline \multicolumn{5}{|l|}{ Chordata - Ascidiacea } \\
\hline Phallusia nigra Savigny, 1816 & & & $x$ & $x$ \\
\hline Lissoclinum cf. abdominale Monniot, 1983 & & & & $x$ \\
\hline Symplegma rubra Monniot, 1972 & $x$ & & & $x$ \\
\hline Didemnum cineraceum (Sluiter, 1898) & & & $x$ & \\
\hline Clavelina oblonga Herdman, 1880 & & & $x$ & \\
\hline \multicolumn{5}{|l|}{ Bryozoa } \\
\hline Schizoporella sp. & & $x$ & $x$ & $x$ \\
\hline \multicolumn{5}{|l|}{ Echinodermata } \\
\hline Echinometra lucunter (Linnaeus, 1758) & & & $x$ & \\
\hline Isostichopus badionotus (Selenka, 1867) & & $x$ & & $x$ \\
\hline TOTAL & 3 & 8 & 12 & 17 \\
\hline
\end{tabular}

Ilha Grande Bay (Creed et al. 2007) we expect that other host species will be found. For example, within the region but outside the study sites during other fieldwork, O. mirabilis was also found on another sea urchin, Lytechinus variegatus (Lamarck, 1816), on the starfish Linckia guildingi Gray, 1840, on the cnidarian Parazoanthus sp., on undetermined algal turfs, on Sargassum spp., on the sponges Mycale laxissima (Duchassaing \& Michelotti, 1864), Aplysina fulva (Pallas, 1766) and Haliclona sp. and even on the prehensile tail of the seahorse Hippocampus reidi Ginsburg, 1933 (M.C.M., personal observation), totaling, with the above sponges (Hajdu et al. (2011), 33 taxons/functional groups used as host for O. mirabilis in Brazil, a total higher than was previously mentioned by Hendler et al. (2012). The seahorse $H$. reidi uses a prehensile tail to keep close to the substrate and spends most part of the time anchored on branches, stones, algae, corals, sponges and others (Silveira 2011), which are generally the same species used by $O$. mirabilis reported here. Thus, it is possible that the ophiuroids crawled onto the seahorse prehensile tail. As a vagile organism, the seahorse could represent an unwitting host for the local range expansion of the hitchhiking ophiuroid, as do the sedentary echinoderms L. guildingi, L. variegatus, E. lucunter and I. badionotus and fragments of algae and other invertebrates via rafting.

In the present study we report the occurrence of $O$. mirabilis at four sites at Ilha Grande Bay (no deeper than $6 \mathrm{~m}$ ) where we know that environmental conditions and stressors were different between the studied sites (Creed et al. 2007). Beyond the study sites, at other locations within the region, the epibiont has also been found at different depths (up to $14 \mathrm{~m}$, unpublished data). These occurrences, together with their distribution along the extensive Brazilian coastline, suggest that this invasive ophiuroid can supports a wide range of environmental conditions and stressors. It is likely that the absence of $O$. mirabilis at one site studied here was due to the fact that the range expansion is ongoing and it 
has not yet arrived at the site, rather than because of unsuitable conditions.

In general the ophiuroids $O$. mirabilis found in this study (color from yellow to orange) did not seem to have any preference or correlation with the color of its host (Figs. 2, 3, 4 and 5) and highly contrasted with dark substrates such as $P$. nigra, for example. In contrast Clark (1976) report the color matching between Ophiothela sp. and gorgonians and Granja-Fernández et al. (2014) observed that $O$. mirabilis has a variety of colors (purple rosaceous, creamy, burgundy and yellow) that were correlated with the color of the hosts. This observation suggests that color may be an important camouflage for some lineages, but did not seem to be important to the yellow-orange lineage in Brazil, maybe because it possesses an innate predator deterrent such as chemical defense. Only future manipulative experiments can indicate whether the ophiuroids actively chose hosts or if they trust random encounters based on availability. Although other associations between ophiuroids and their biological substrates have been classified as commensalism, with no harm to the host, the very high densities of $O$. mirabilis registered here suggests the potential for negative effects. Even though the epibiont would not feed on the host, its presence can still baffle water currents, interrupt feeding structures and polyp extension, or increase total weight and subject the host to higher drag forces. More detailed future research is needed to address the positive or negative interactions of $O$. mirabilis on its hosts and the community in general.

\section{Conclusions}

At Ilha Grande Bay, Brazil, the invasive brittle star Ophiothela mirabilis has at least 29 novel host taxons/ functional group (ten sponges, six cnidarians, five ascidians, four echinoderms, two algae, one bryozoan and a seahorse). This suggests that it is opportunistic and generalist in relation to its host species. The yellow-orange Brazilian lineage did not use camouflage reported in other studies, as they were highly visible and contrasted in color to many host species. The high abundances of $O$. mirabilis suggest potential impacts to their hosts which need further study.

\section{Methods}

\section{Study area}

The present study was carried out at Ilha Grande Bay a large tropical embayment south of Rio de Janeiro, Brazil. The region has been characterized as extremely rich in benthic species, a biodiversity sanctuary with more than 900 species of macroalgae, echinoderms, cnidarians, mollusks, crustaceans and polychaetes described (Creed et al. 2007). However, the same study showed that its biodiversity is subjected to a number of human pressures, including the presence of marinas, harbors, ports and an oil terminal that contribute to high marine traffic including ships and oil platforms that are vectors of marine NIS. The shallow rocky reef communities in the region are dominated by the zoanthid Palythoa caribaeorum and algal turfs (Lages et al. 2011).

In order to register the host species of O. mirabilis, five representative rocky reefs no deeper than $6 \mathrm{~m}$ were selected in the region: Lagoa Azul (23 $5.047^{\prime} \mathrm{S}$; $44^{\circ}$ $\left.14.137^{\prime} \mathrm{W}\right)$, Barretos $\left(23^{\circ} 6.242^{\prime} \mathrm{S}\right.$; $\left.44^{\circ} 11.550^{\prime} \mathrm{W}\right)$, Morcegos $\left(23^{\circ} 7.822^{\prime} \mathrm{S} ; 44^{\circ} 8.949^{\prime} \mathrm{W}\right)$, Abraãozinho right $\left(23^{\circ}\right.$ $\left.8.016^{\prime} \mathrm{S} ; 44^{\circ} 9.054^{\prime} \mathrm{W}\right)$ and Abraãozinho left $\left(23^{\circ} 8.065^{\prime} \mathrm{S}\right.$; $44^{\circ}$ 9.254 $\mathrm{W}$ ) (Fig. 1b). The sites were chosen using information in Creed et al. (2007) based on locations with similar species richness but representing a range of environmental conditions including stressors.

\section{The sampled population}

The five sites were visited in September 2014. At each site two snorkelers swam parallel to the rocky reefs during $30 \mathrm{~min}, \leq 6 \mathrm{~m}$ depth, looking for $O$. mirabilis and its hosts. Species colonized by the ophiuroid were recorded with a Canon PowerShot G15 digital camera with a waterproof case, identified in situ or collected for identification in the laboratory using standard taxonomic techniques for the taxons in question.

\section{Availability of supporting data}

The dataset supporting the conclusions of this article is included within the article as photographs.

\section{Competing interests \\ The authors declare that they have no competing interests.}

\section{Authors' contributions}

MCM carried out fieldwork, took the photographs, identified organisms and wrote the maunscript with contributions from all other authors. LFV carried out fieldwork, took the photographs and identified organisms. RBS, CM and RMR obtained funding and identified organisms. JCC designed the study, obtained funding and identified organisms. All authors read and approved the final manuscript.

\section{Acknowledgements}

We thank two anonymous reviewers for their comments. M.C.M. acknowledges Coordenação de Aperfeiçoamento de Pessoal de Nível Superior (CAPES) that provide a PhD scholarship. R.B.S acknowledges Petrobras, through the Programa Petrobras Socioambiental. This study was carried out under SISBIO license No 40311-2 and INEA license No 043/2014. This work was supported by Coordenação de Aperfeiçoamento de Pessoal de Nível Superior (J.C.C., Ciências do Mar 1137/2010); Fundação Carlos Chagas Filho de Amparo à Pesquisa do Estado do Rio de Janeiro (J.C.C., FAPERJ-E-26/ 111.574/2014 and E26/201.286/2014); Fundação de Amparo à Pesquisa do Estado da Bahia (C.M., FAPESB-APP-0031/2011); and Conselho Nacional de Desenvolvimento Científico e Tecnológico (C.M., CNPq-486548/2011-2), (J.C.C., CNPq-305330/2010-1), (R.M.R., CNPq-305201/2014-0).

\section{Author details}

${ }^{1}$ Programa de Pós-Graduação em Ecologia e Evolução, Instituto de Biologia Roberto Alcântara Gomes, Universidade do Estado do Rio de Janeiro, Rua Francisco Xavier, 524, PHLC, sala 220, CEP 20559-900 Rio de Janeiro, RJ, Brazil. ${ }^{2}$ Laboratório de Aquicultura Marinha, Projeto Hippocampus, Rua da Esperança, s/n, CEP 55590-000, Caixa Postal 224, Ipojuca, PE, Brazil. 
${ }^{3}$ Departamento de Zoologia, Instituto de Biologia, Universidade Federal da Bahia, Rua Barão de Jeremoabo, s/n, CEP 40170-180 Salvador, BA, Brazil. ${ }^{4}$ Departamento de Zoologia, Universidade Federal do Paraná, CEP 81531-980Caixa Postal 19020, Curitiba, PR, Brazil. . Departamento de Ecologia, Instituto de Biologia Roberto Alcântara Gomes, Universidade do Estado do Rio de Janeiro, Rua Francisco Xavier 524, PHLC, sala 220, CEP 20559-900 Rio de Janeiro, RJ, Brazil. ${ }^{6}$ Coral-Sol Research, Technological Development and Innovation Network, Rio de Janeiro, Brazil.

Received: 17 February 2016 Accepted: 23 February 2016

Published online: 30 March 2016

\section{References}

Alvarado JJ, Fernández C. Equinodermos del Parque Nacional Marino Ballena, Pacífico, Costa Rica. Rev Biol Trop. 2005;53:275-84.

Cañete Il, Rocha RM. Modiolarca lateralis (Pteryomorphia: Mytilidae): bivalve associated to six species of ascidians from Bocas del Toro. Panama Lat Am J Aquat Res. 2013;41(5):1030-5.

Clark AM. Tropical epizoic echinoderms and their distribution. Micronesica. 1976; 12(1):111-8.

Collin R, Díaz MC, Norenburg J, Rocha RM, Sánchez JA, Schulze A, et al. Photographic identification guide to some common marine invertebrates of Bocas del Toro, Panama. Caribb J Sci. 2005;41(3):638-707.

Creed JC, Pires DO, Figueiredo MAO. Biodiversidade Marinha da Baía da Ilha Grande. Brasília: Ministério do Meio Ambiente (MMA); 2007.

Goodbody I. The Biology of Ascidia nigra (Savigny). I. Survival and mortality in an adult population. Biol Bull. 1962;122(1):40-51.

Granja-Fernández MR, López-Pérez RA. Nuevos registros de ofiuroideos (Echinodermata: Ophiuroidea) para localidades de Zihuatanejo (Guerrero) y Puerto Escondido (Oaxaca), Pacífico mexicano. Rev Mex Biodivers. 2011;82: $1320-3$.

Granja-Fernández R, Herrero-Pérezrul MD, López-Pérez RA, Hernández L, Rodríguez-Zaragoza FA, Jones RW, et al. Ophiuroidea (Echinodermata) from coral reefs in the Mexican Pacific. Zookeys. 2014;406:101-45.

Hajdu E, Peixinho S, Fernandez JCC. Esponjas marinhas da Bahia: guia de campo e laboratório. Rio de Janeiro: Museu Nacional; 2011.

Hendler G, Brugneaux SJ. New records of brittle stars from French Guiana: Ophiactis savignyi and the alien species Ophiothela mirabilis (Echinodermata: Ophiuroidea). Mar Biodivers Rec. 2013:6:1-5.

Hendler G, Baldwin CC, Smith DG, Thacker CE. Planktonic dispersal of juvenile brittle stars (Echinodermata: Ophiuroidea) on a Caribbean reef. Bull Mar Sci. 1999;65:283-8.

Hendler G, Migotto AE, Ventura CRR, Wilk L. Epizoic Ophiothela brittle stars have invaded the Atlantic. Coral Reefs. 2012;31:1005.

Hickman CP. A field guide to sea stars \& other echinoderms of Galapagos. Virginia: Sugar Spring Press; 1998.

Lages BG, Fleury BG, Menegola C, Creed JC. Change in tropical rocky shore communities due to an alien coral invasion. Mar Ecol Prog Ser. 2011;438:85-96.

Mladenov PV, Emson RH. Density, size structure and reproductive characteristics of fissiparous brittle stars in algae and sponges: evidence for interpopulational variation in levels of sexual and asexual reproduction. Mar Ecol Prog Ser. 1988;42:181-94.

Mladenov PV, Emson RH, Colpit LV, Wilkie IC. Asexual reproduction in the west Indian brittle star Ophiocomella ophiatoides (HL. Clark) (Echinodermata: Ophioroidea). J Exp Mar Biol Ecol. 1983;72:1-23.

Monniot C, Monniot F, Laboute P. Coral reef ascidians of New Caledonia. Paris: Editions de l'Orstom; 1991.

Mosher CV, Watling L. Partners for life: a brittle star and its octocoral host. Mar Ecol Prog Ser. 2009;397:81-8.

Neira RO, Cantera JRK. Composición taxonómica y distribución de las asociaciones de equinodermos en los ecosistemas litorales del Pacifico Colombiano. Rev Biol Trop. 2005;53:195-206.

Osman RW, Whitlatch RB. The influence of resident adults on recruitment: a comparison to settlement. J Exp Mar Biol Ecol. 1995;190:169-98.

Pimentel D, Zuniga R, Morrison D. Update on the environmental and economic costs associated with alien-invasive species in the United States. Ecol Econ. 2005;52(3):273-88.

Ruiz GM, Carlton JT, Grosholz ED, Hines AH. Global invasions of marine and estuarine habitats by non-indigenous species: mechanisms, extent, and consequences. Am Zool. 1997;37(6):621-32.
Silveira RB. Registros de cavalos-marinhos (Syngnathidae: Hippocampus) ao longo da costa Brasileira. Oecol Bras. 2011;15(2):316-25.

Sivadas SK, Redij A, Sagare P, Thakur N, Ingole BS. Temporal variation in macroinvertebrates associated with intertidal sponge Ircinia fusca (Carter 1880) from Ratnagiri, West coast, India. Indian J Geomarine Sci. 2014;43(6):921-6

Stoecker D. Resistance of a tunicate to fouling. Biol Bull. 1978;155:615-26.

Tahera Q. Echinoderms epizoic on gorgonian corals from Karachi Coast. Pak J Biol Sci. 2001:4(9):1177-9.

\section{Submit your next manuscript to BioMed Central} and we will help you at every step:

- We accept pre-submission inquiries

- Our selector tool helps you to find the most relevant journal

- We provide round the clock customer support

- Convenient online submission

- Thorough peer review

- Inclusion in PubMed and all major indexing services

- Maximum visibility for your research

Submit your manuscript at www.biomedcentral.com/submit 